\title{
APPLYING TWO STAY TWO STRAY (TSTS) TECHNIQUE BY USING PICTURE SERIES TO IMPROVE STUDENTS' SPEAKING SKILL AT THE SECONDGRADE IN MAN 2 PAREPARE
}

\author{
Rasdiana ${ }^{1}$, Abu Bakar Juddah2, Amzah Selle ${ }^{3}$ \\ English Program, Tarbiyah Faculty, State Islamic Institute of Parepare ${ }^{123}$ \\ Rassrasdiana393@gmail.com ${ }^{1}$
}

\begin{abstract}
The purpose of this research was positively to find out whether applying two stay two stray technique by using picture series to improve students' speaking skill at the second grade in MAN 2 Parepare. The results of this research, the benefit for the teacher and students. The teacher will be conscious that it is important to apply the technique in teaching. The students can enjoy the lesson so they can be easier to express their ideas and also confidence to speak by using the gesture. The subject of this research is XI MIA 1 class which is consisted of 27 students. The sample was taken by using purposive sampling. The design in this research was pre-experimental with pre-test and post-test design. The student did the pre-test, got the treatment and did the post-test. It aimed to know whether applying two stays two stray technique by using picture series can improve students' speaking skill. The result in this research was indicated that the improvement of the students' speaking skill. It was indicated by the students' mean score of post-test (72.26) was greater than pre-test (44.46). Even, for the level significant (p) $5 \%$ and $\mathrm{df}=26$, and the value of table is 1.706 , while the value of t-test is 18.34 . It means that the t-test value is greater than t-table $(2.29 \geq 1.706)$. Thus, it can be concluded that the students' speaking skill is significantly better after getting the treatment. So, the null hypothesis $\left(\mathrm{H}_{0}\right)$ is rejected and the alternative hypothesis $\left(\mathrm{H}_{\mathrm{a}}\right)$ is fail rejected.
\end{abstract}

Keywords: Speaking Skill, Two Stay Two Stray and Picture Series. 


\section{Introduction}

Indonesia students in a school have to learn English as one of the target languages, because English is the first foreign language that taught at school. They need to learn both language skills such as listening, reading, writing, speaking and also language elements such as pronunciation, vocabulary and structure. Language is tool of communication used by the human being community in their interaction. As people know, English is International language. So, to communicate each other in the world people should know English.

The process of learning foreign language e.g English there are four kinds of skills namely listening, reading, speaking, and writing. These skills are required to master in communication both in spoken and written discourses. As for the learners, speaking skill is the most preferred skill among the other. As Richards in Kaharuddin state that, a large percentage of the world's language learners study English in order to develop proficiency in speaking (Kaharuddin, 2015)

Actually, all English skills and English elements are important, but speaking skill is most important skill for learners. People can express their ideas and feelings orally by speaking and people can describe things, give direction complain about people's behavior, make polite request, or entertain people with jokes, because people use speaking for a variety of different purpose.

In fact, there are many students are still poor in speaking. Such as, students still don't know how to express their ideas and feelings, they are difficult to communicate each other by using English, and in the class five of twenty-seven students can speak English, and they are confident to express their ideas and feeling, there are also some of them know how to speak but not confident. Only five of them always speak up in the class, the other students still shy to speak up.

Based on the problems, the researcher interests to solve the problems by applying a technique in cooperative learning model namely Two Stay Two Stray (TSTS) Technique, and researcher will use picture series to make students more interest in speaking. This technique can help students to explain things, because they 
work in team that we call cooperative learning. They will discuss with their team, and then they will visit the other group to explain their groupmatearguments. So not only five students speak up but almost all students will speak up.

\section{Method}

The research design of this research was pre-experimental with pre-test and post-test. It aimed to know whether applying two stay two stray technique in cooperative learning by using picture series can improve the student's speaking skill at the second grade in MAN 2 Parepare. The following is the formula:

$$
\mathrm{E}=\mathrm{O} 1 \times \mathrm{O} 2
$$

Where:

E : Experimental Group

O1 : Pre-test

X : Treatment

O2 : Post-test

The locationof the research took a place at MAN 2 Parepare. The research used the quantitative research that have several times to collect and analyze data. The researcher did the research around one month for collecting data.

The population of the research was the second year students of MAN 2 Parepare academic year 2018/2019. There were 6classes in that school which were XI.Mia 1, XI.Mia 2, X.Mia 3, XI.Iis 1, XI.Iis 2, and XI.Iis 3. The total of populationwere 144 students.

The samplewas taken by usingpurposivesampling. The researcher used this technique because the researcher has purpose so the sample took from the researcher is class XI.Mia 1. the class XI.Mia 1 which was consists of 27 students as the sample in this research.

In collecting data, the researcher tested the students' speaking skill by giving questions about unforgettable moment in pre-test and holiday post-test and the 
researcher recorded by voice recorder. The pre-test was intended to see students' speaking skill before giving treatment, while the post-test was intended to know the students' improvement in speaking. The researcher asked totell about unforgettable moment in measuring students' speaking skill before applying two stay two stray technique by using picture series in the pre-test. The researcher asked to tell about telling a holiday to know the improvement after applying two stay two stray technique by using picture series in post-test.

Table 1 Scoring Formulation for Students' Speaking Skill

\begin{tabular}{ccl}
\hline Classification & Score & \multicolumn{1}{c}{ Criteria } \\
\hline Fluency & $9-10$ & Directly explain completely \\
& $7-8$ & Explain completely while thinking \\
& $5-6$ & Explain but not complete \\
& $3-4$ & Explain while thinking but not complete \\
& $1-2$ & Purpose is not clear, needs a lot of communicating \\
& $9-10$ & usually does not respond. \\
& $7-8$ & No mistake \\
Accuracy & $5-6$ & One inaccurate \\
& $3-4$ & Two inaccurate word \\
& $1-2$ & More than three inaccurate \\
& $9-10$ & Message required is dealt with effectively \\
& $7-8$ & Message required is dealt with effectively but a \\
& little unsystematic \\
& $5-6$ & Message required is adequately conveyed and \\
& & organized but some lost of detail \\
& $3-4$ & Message is broadly conveyed but with little \\
& subtlety and some lost of detail \\
& $1-2$ & Inadequate or irrelevant attempts at conveying the \\
& message \\
& $9-10$ & Very good pronunciation \\
& $7-8$ & Good pronunciation \\
& $5-6$ & Fair pronunciation \\
& $1-2$ & Poor pronunciation \\
& Very poor pronunciation \\
& &
\end{tabular}

(Data' source of MAN 2Parepare) 
Table 2 The Classification Students'Score.

\begin{tabular}{cc}
\hline Classification & Score \\
\hline Very good & $81-100$ \\
Good & $61-80$ \\
Fair & $41-60$ \\
Poor & $21-40$ \\
Very poor & $0-20$ \\
\hline
\end{tabular}

\section{Result}

The researcher gave some questions to the students' as the pre-test to know the students' speaking skill. Every student got the questions and answered it then the researcher recorded the students' answers. After giving the pre-test to the students, the researcher found out the result of students' speaking skill based on the criteria of speaking skill which are fluency, accuracy, content and pronunciation before giving treatment.

Table 3 The Students' Speaking Score in Pre-test

\begin{tabular}{cccccc}
\hline \multirow{2}{*}{ No. } & Name & \multicolumn{4}{c}{ Pre-Test of Students $\left(\mathbf{X}_{\mathbf{1}}\right)$} \\
\cline { 3 - 6 } & Max Score & Total Score $\left(\mathbf{X}_{\mathbf{1}}\right)$ & $\mathbf{( \mathbf { X } _ { \mathbf { 1 } } ) ^ { \mathbf { 2 } }}$ & Classifucation \\
\hline 1 & AF & 40 & 50 & 2500 & Fair \\
2 & AM & 40 & 55 & 3025 & Fair \\
3 & AP & 40 & 48 & 2304 & Fair \\
4 & IM & 40 & 30 & 900 & Poor \\
5 & IS & 40 & 35 & 1225 & Poor \\
6 & JD & 40 & 35 & 1225 & Poor \\
7 & MS & 40 & 48 & 2304 & Fair \\
8 & MT & 40 & 35 & 1225 & Poor \\
9 & MF & 40 & 40 & 1600 & Poor \\
10 & MW & 40 & 68 & 4624 & Good \\
11 & MY & 40 & 45 & 2025 & Fair \\
12 & MA & 40 & 30 & 900 & Poor \\
13 & MD & 40 & 50 & 2500 & Fair \\
14 & MH & 40 & 63 & 3969 & Good \\
15 & NW & 40 & 50 & 2500 & Fair \\
16 & NH & 40 & 45 & 2025 & Fair \\
17 & NF & 40 & 35 & 1225 & Poor
\end{tabular}




\begin{tabular}{llllcl}
18 & NH & 40 & 35 & 1225 & Poor \\
19 & PD & 40 & 43 & 1849 & Fair \\
20 & RW & 40 & 70 & 4900 & Good \\
21 & RP & 40 & 35 & 1225 & Poor \\
22 & RT & 40 & 45 & 2025 & Fair \\
23 & RS & 40 & 55 & 3025 & Fair \\
24 & SL & 40 & 40 & 1600 & Poor \\
25 & UZ & 40 & 48 & 2304 & Fair \\
26 & WT & 40 & 35 & 1225 & Poor \\
27 & DZ & 40 & 35 & 1225 & Poor \\
\hline \multicolumn{7}{r}{} & Total & & &
\end{tabular}

(Data' Source: the students' score in pre-test)

Based on table above about students' speaking in the pre-test we can know the frequency of the classification score by looking the following table

Table 4 The Rate Percentage of the Frequency of the Pre-test

\begin{tabular}{ccccc}
\hline No. & Classification & Score & Frequency of Pre-Test & Percentage of Pre-Test \\
\hline 1. & Very Good & $81-100$ & 0 & $0 \%$ \\
2. & Good & $61-80$ & 3 & $11.1 \%$ \\
3. & Fair & $41-60$ & 12 & $44.4 \%$ \\
4. & Poor & $21-40$ & 12 & $44.4 \%$ \\
5. & Very poor & $0-20$ & 0 & $0 \%$ \\
\hline \multicolumn{7}{r}{ Total } & $\mathbf{2 7}$ & $\mathbf{1 0 0 \%}$ \\
\hline
\end{tabular}

(Data source: The rate percentage of the frequency of pre-test)

As the illustrated in the table above, the average score of students' prior speaking skill before applying two stays two stray technique by using picture series. There were three students got the good score, twelve students got the fair score and twelve students got the poor score. The total score in the pre-test was 1203. It had shown that the students' speaking skill in the pre-test was low, because most of the students got fair and poor score.

After knowing the students' score in post-test based on the criteria of speaking skill which are fluency, accuracy, content, and pronunciation. The following table below is to know students speaking score in post-test: 
Table 5 The students' Speaking Score in Post-test

\begin{tabular}{|c|c|c|c|c|c|}
\hline \multirow{2}{*}{ No. } & \multirow{2}{*}{ Name } & \multicolumn{4}{|c|}{ Post-Test of Students $X_{2}$} \\
\hline & & Max Score & Total Score $\left(\mathbf{X}_{2}\right)$ & $\left(\mathbf{X}_{2}\right)^{2}$ & Classifucation \\
\hline 1 & $\mathrm{AF}$ & 40 & 88 & 7744 & Very Good \\
\hline 2 & $\mathrm{AM}$ & 40 & 78 & 6084 & Good \\
\hline 3 & $\mathrm{AP}$ & 40 & 68 & 4624 & Good \\
\hline 4 & IM & 40 & 68 & 4624 & Good \\
\hline 5 & IS & 40 & 70 & 4900 & Good \\
\hline 6 & $\mathrm{JD}$ & 40 & 68 & 4624 & Good \\
\hline 7 & MS & 40 & 73 & 5329 & Good \\
\hline 8 & MT & 40 & 80 & 6400 & Good \\
\hline 9 & MF & 40 & 65 & 4225 & Good \\
\hline 10 & MW & 40 & 88 & 7744 & Very Good \\
\hline 11 & MY & 40 & 63 & 3969 & Good \\
\hline 12 & MA & 40 & 68 & 4624 & Good \\
\hline 13 & MD & 40 & 70 & 4900 & Good \\
\hline 14 & MH & 40 & 80 & 6400 & Good \\
\hline 15 & NW & 40 & 73 & 5329 & Good \\
\hline 16 & $\mathrm{NH}$ & 40 & 70 & 4900 & Good \\
\hline 17 & NF & 40 & 63 & 3969 & Good \\
\hline 18 & $\mathrm{NH}$ & 40 & 70 & 4900 & Good \\
\hline 19 & PD & 40 & 70 & 4900 & Good \\
\hline 20 & RW & 40 & 83 & 6889 & Very Good \\
\hline 21 & $\mathrm{RP}$ & 40 & 68 & 4624 & Good \\
\hline 22 & RT & 40 & 70 & 4900 & Good \\
\hline 23 & $\mathrm{RS}$ & 40 & 88 & 7744 & Very Good \\
\hline 24 & SL & 40 & 73 & 5329 & Good \\
\hline 25 & UZ & 40 & 70 & 4900 & Good \\
\hline 26 & WT & 40 & 58 & 3364 & Fair \\
\hline 27 & DZ & 40 & 68 & 4624 & Good \\
\hline
\end{tabular}

(Data' Source: the students' score inpost-test)

The table above shows about students' speaking score in post-test. To find out the students' speaking score in post-test by dividing students' total score with maximum score, after that times with 100. Based on table above about students' speaking score in post-test we can know the frequency of the classification score by looking the following table:

Table 6 The Rate Percentage of the Frequency of the Post-test 


\begin{tabular}{ccccc}
\hline No. & Classification & Score & Frequency of pre-test & Percentage of pre-test \\
\hline 1. & Very Good & $81-100$ & 4 & $14.8 \%$ \\
2. & Good & $61-80$ & 22 & $81.5 \%$ \\
3. & Fair & $41-60$ & 1 & $3.7 \%$ \\
4. & Poor & $21-40$ & 0 & $0 \%$ \\
5. & Very poor & $0-20$ & 0 & $0 \%$ \\
\hline & Total & 27 & $100 \%$ \\
\hline
\end{tabular}

(Data' source: The rate percentage of the frequency of post-test)

The table above, shows the result of students' improvement in speaking skill after applying treatment through two stays two stray technique by using picture series. There were four students got very good score and twenty-two students got good score and one student got fair score. It means that the students' speaking skill had improved through applying two stays two stray technique by using picture series. The total score in post-test was 1951. It proved that there were improving of students' score in post-test. In addition, the result of post-test showed that no students had poor classification.

In this table, the researcher analysed the data of students' score in post-test to know whether there is or there is no a significant different of students' achievement before and after learning process in applying two stay two stray technique by using picture series in speaking skill.

Table 7 The Mean Score and Standard Deviation of Pre-test and Post-test

\begin{tabular}{ccc}
\hline Test & Mean Score & Standard Deviation (SD) \\
\hline Pre-test & 44.46 & 10.88 \\
Post-test & 72.26 & 7.81 \\
\hline
\end{tabular}

(Data' source: The mean score and standard deviation of pre-test and post-test)

The data in table 4.7. Shows that the mean score of pre-test was $44.46\left(\mathrm{X}_{1}\right)$ while the mean score of the post-test increased $72.26\left(\mathrm{X}_{2}\right)$. The standard deviation of pre-test was 10.88 while the standard deviation of post-test was 7.81. Standard deviation in pre-test was 10.88 , it means the students' speaking skill different or the students' speaking skill far, after giving treatment each students have almost same speaking skill or the students' speaking skill not far. it proved from standard deviation in post-test was 7.81 . 
As the result in this item is the mean score of the post-test was greater than the mean score in pre-test. It means that students' speaking skill had improvement after doing the learning process that applying two stay two stray technique by using picture series.

Table 8 The Rate Percentage of the Frequency of the Pre-test and Post-test

\begin{tabular}{ccccccc}
\hline & & \multicolumn{2}{c}{ Frequency } & \multicolumn{2}{c}{ Percentage } \\
\cline { 3 - 6 } No. & Classification & Score & Pre-Test & Post-Test & Pre-Test & Post-Test \\
\cline { 3 - 6 } & & & & & & \\
\hline 1. & Very Good & $81-100$ & 0 & 4 & $0 \%$ & $14.8 \%$ \\
2. & Good & $61-80$ & 3 & 22 & $11.1 \%$ & $81.5 \%$ \\
3. & Fair & $41-60$ & 12 & 1 & $44.4 \%$ & $3.7 \%$ \\
4. & Poor & $21-40$ & 12 & 0 & $44.4 \%$ & $0 \%$ \\
5. & Very Poor & $0-20$ & 0 & 0 & $0 \%$ & $0 \%$ \\
& Total & & 27 & 27 & $100 \%$ & $100 \%$ \\
\hline
\end{tabular}

(Data source: the rate percentage of thefrequency of the pre-test and post-test)

The data of the table above indicated that rate percentage of the pre-test three (11.1\%) students got the good score, twelve (44.4\%) students got the fair score, and twelve $(44.4 \%)$ students got the poor score while the rate percentage of the post-test, four $(14.8 \%)$ students got the very good score, twenty-two $(81.5 \%)$ students got the good score and one $(3.7 \%)$ student got the fair score. The percentage in the post-test that students got the very good score was higher than percentage in the pre-test. It showed that students were able to improve the students' speaking skill after treatment through applying two stay two stray technique by using picture series.

Table 9 The Test of Significant

\begin{tabular}{ccc}
\hline Variable & T-test & T-table value \\
\hline Pre-test - post-test & 18.34 & 1.706 \\
\hline (Data source: Primary data processing) & &
\end{tabular}

\section{Discussion}

From the previous result, it showed that the improvement of students' speaking skill through applying two stay two stray technique by using picture series 
because the mean score of the pre-test was 44.46 and the mean score of post-test was 72.26. The researcher concludes that the mean score of students' before giving the treatment is lower than the mean score of students' after giving the treatment.

The researcherapplied two stay two stray technique by using picture series in teaching speaking to make the students were easier to express their idea. The researcher measured the students' speaking by focusing on the aspect of speaking which are fluency, accuracy, content, and pronunciation. These aspects also were a guideline for the researcher in scoring students' speaking.

The data provided in a classification table based on the aspects of speaking from the test finding. There was an improvement skill after giving the treatment because the students score in the pre-test was 44.46and it was very low score then the score of the post-test was 72.26 and it was very high score. In the pre-test, three $(11.1 \%)$ students got the good score, twelve (44.4\%) students got the fair score, and twelve $(44.4 \%)$ students got the poor score. Whilefour $(14.8 \%)$ students got the very good score, twenty-two (81.5\%) students got the good score and one (3.7\%) student got the fair score in the post-test. From the result, the researcher concluded that the students speaking skill from poor to good score, also from fair to very good score.

After finished doing the research, the students felt happy and fun in learning English by applying two stays two stray technique by using picture series. They were easier to express their ideas because of there were picture series, and they felt fun because they discussed with their group after that shared with the other group. So they were not only interacting with their group but also the other group. It would make them speaking, not only some of them but all students speaking.

In teaching English through applying two stay two stray technique by using picture series had impact in improving the students' speaking skill. In fact, based on the finding most students have a good score in post-test. It means that, applying two stay two stray technique by using picture series effective to be used in improving students' speaking skill. This model learning helped the student to express their ideas, 
and the media could make they were easier to speak, so they would not confuse to speak and communicate with each another.

The students express their ideas in speaking with a different theme for each meeting. It was hoped to make the students confident to express their ideas and make easier to speak and also develop their ideas. Applying two stays two stray technique by using picture series in learning to speak was able to help the students to speak English completely and fluently. As the conclusion, applying two stays two stray technique by using picture series had an impact in improving the students' speaking skill.

\section{Conclusions}

Based on the result of data analysis and the discussion of the result in previous chapter, the finding of the result showed the positive impact in the students' speaking skill and class situation. This study is categorized pre-experiment research design, the objective in this study is to find out whether applying two stay two stray technique by using picture series was able or not to improve the students' speaking skill. Therefore, the researcher concluded that there was a significant difference of the students' speaking skill before and after treatment. The following are the description of the conclusion based on the problem statement of this research: T-test result in which the value of t-test was 18.34. It was greater than t-table was 1.706 at the level significance 0.05 and degree of freedom (df) was 26. The mean score of pre-test (44.46), standard deviation (10.88), and the mean score of post-test (72.26) and the standard deviation (7.81).

Based on the description of the result above, it can be proved by looking at the

mean score of the students' speaking test in pre-test and post-test. The mean score of pre-test (44.46) is lower than the mean score of post-test (72.26). Then, the t-test (18.34) was greater than t-table (1.706). it means that the null hypothesis $\left(\mathrm{H}_{0}\right)$ was rejected and the alternative hypothesis $\left(\mathrm{H}_{\mathrm{a}}\right)$ was accepted. 


\section{References}

Arikunti, suharsimi. 2009. Dasar-Dasar Evaluasi pendidikan. Jakarta: Bumi Aksara.

Arsyad, Azhar. 2004. Media Pembelajaran. Jakarta : PT Raja Grafindo Persada.

Bahar, A. Kaharuddin. 2014. Interactional Speaking. Yogyakarta: Trustmedia Publishing. Transactional Speaking. Samata-Gowa: Gunadarma Ilmu.

Basyirun, Fajrin. 2017. "Model Pembelajaran Two Stay Two Stray" http://fbasyirun.blogspot.co.id/2013/02/model-pembelajarantwostaytwostray.html. (Accesed on December $1^{\text {st }}$ ).

Bungin, Burhan. 2005. Metode Penelitian Kuantitatif Jakarta: Kencana Pradana Media.

Darsini, Ni Wayan. 2013. "Impproving Speaking Skill Though Cooperative Learning Method of the Eight Grade Students of SMPN 2 UBUD IN Academic 2012/2013". Published Scrips; English Department Faculty of Teacher Training and Education Mahasaraswati Denpasar University: Denpasar.

David, Edward and Allen. 1972. Classroom Techniques: Foreign Languages and English as a Second Language. New York: Harcourt Brace Jovanovich.

E Slavin, Robert. 1982. Cooperative Learning: Studen Teams. United States: library of Congress in Publication Data.

Fathurrohman,Muhammad.2015. Model-model PembelajaranInovatif. Jogyakarta: Ar-ruzz Media.

Fatoni, Nur. 2014. "The Influence of Using Two Stay Two Stray in Learning Reading Comprehension of Recount Text". Published Scrips; English Education Fakulty of Tarbiyah and Teachers Training Syarif Hidayatullah: Jakarta.

Gay L.R. 1981. Educational Research Competencies for Analysis and Application. second edition. Columbus: Charles E. Meril Publising Company.

Hanawati. 2013. "Using Two Stay Two Stray Method In IncreasingStudents' Speaking Ability Of The Second Year Students Of SMP Negeri 1 Mallusetasi”. UnpublishedScrips; English ProgramTarbiyahDepartmentState Islamic College (STAIN): Parepare.

Harmer, Jeremy. 2002. The Practice of English Language Teaching ; Fourt Edision. England Longman Pearson.

Huda, Miftahul. 2017. Cooperative Learning Metode, Teknik, Strukturdan Model Penerapan. Yogyakarta: PustakaBelajar. 
MCDonough, Jo and Christopher Shaw. 2013. Material and Methods in ELT: A Teacher Guide. Cambridge: Black well Publisher.

Nation. I.SP. 1990. Teaching and Learning Vocabulary. United States of America: Heinle \& Heinle Publisher.

Nurfatoni. 2014. "The Influence of Using Two Stay Two Stay Technique in Learning Reading Comprehension ( A Quasi Experimental Research at Second Grade Students of SMA Dharma Karya UT Pondok Cabe Ilir, Pamulang, Tanggerang Selatan, Banten)". Published Scrips; English Education Facultyof Tarbiyah and Teachers Training Syarif Hidayatullah: Jakarta.

Nurhayati, Dwi Astuti Wahyu. 2017. “Using Picture Series to Inspire Reading Comphension For the Second Semester Students of English Department of IAIN Tulungagung ". Journal of Dinamika Ilmu. Vol. 14 no. 2 (December 2014), p. 181-182. https://journal.iainsamarida.ac.id/index.php/dinamika_ilmu/article/dowload/14/26. (Accessed on December $2^{\text {nd }}$ ).

Nuryadi. 2017. "Using Picture Series in Teaching Procedure Text to Improve the Students Speaking Ability at Grade Eight of SMP Negeri 2 Deket in the Academic Year 2013/2014". http://journal.unisla.ac.id/pdf/14112015/nuryadi.pdf. (Accessed on December $\left.2^{\text {nd }}\right)$.

Purwatiningsih. 2017. "Improving Speaking Ability Through Story Telling Technique By Using Picture Series". Journal on English as a Foreign Language.Vol 5 no 1. (March 2015). p. 57. http://e-journal.iainpalangkaraya.ac.id/index.pp/jefl/article/viewfile/93/616. (Accessed on December $2^{\text {nd }}$ ).

Riyan, Mochammad. 2017. "The Effectiveness of Using Picture Series as Media to Teach Writing Producedure Text for Tenth Graders of SMA Negeri Babdar Kedung Mulyo Jombang". E-Journal. Vol. 2 no. 2, 2014. http://jurnalmahasiswa.unesa.ac.id/index.php/retain/article/viw/7559. (Accessed on December $2^{\text {nd }}$ ).

Rusman. 2010. Model-model Pembelajaran Mengembangkan Profesionalisme Guru. Jakarta: PT RajaGrafindo Persada.

Sekolah Tinggi Agama Islam Negeri (STAIN). 2013. Pedoman Penulisan Karya Ilmiah. Parepare: Departemen Agama.

Shoran. 2017. "Media Gambar Seri" http://shaoran1401.blogspot.co.id/2014/01/media-gambar-seri.html. (Accessed on December $2^{\text {nd }}$ )

Sudijon, Anas. 2006. Pengantar Statistik Pendidikan. Jakarta: Raja Grapindo Persada. 
Sugiono. 2014. Metode Penelitian Pendidikan. Cet. XX; Bandung : Alfabeta.

. 2015. Metode Penelitian Pendidikan Kuantitatif Kualitatif. Cet. 22;Bandung: Alfabeta.

Suprijono, Agus. 2016. Cooperative Learning; Teori \& Aplikasi Paikem. Yogyakarta: Pustaka Pelajar.

Wright, Andrew .1083. Visual Materials for the Language Teacher. England: Longman Group itd. 